\title{
PENGARUH MODEL PEMBELAJARAN KOOPERATIF TIPE JIGSAW-STAD DAN KECERDASAN INTERPERSONAL TERHADAP HASIL BELAJAR PENDIDIKAN AGAMA KATOLIK
}

\author{
Saidi Perri Marbun, Mukhtar, R. Mursid \\ Sekolah Menengah Atas Swasta Maria Tarutung, Tapanuli Utara \\ saidiperrimarbun@gmail.com
}

\begin{abstract}
Abstrak: tujuan penelitian ini adalah (1) untuk mengetahui perbedaan hasil belajar siswa yang dibelajarkan dengan model pembelajaran kooperatif tipe jigsaw dengan model pembelajaran kooperatif tipe STAD dalam mata pelajaran Pendidikan Agama Katolik; (2) untuk mengetahui perbedaan hasil belajar siswa yang memiliki kecerdasan interpersonal tinggi dengan siswa yang memiliki kecerdasan interpersonal rendah; (3) untuk mengetahui interaksi antara model pembelajaran dan kecerdasan interpersonal dalam mempengaruhi hasil belajar Pendidikan Agama Katolik. Metode dalam penelitian quasi-eksperimen. Desain penelitian faktorial $2 \times 2$. Hasil penelitian menunjukkan bahwa: (1) Hasil belajar Pendidikan Agama Katolik siswa dengan model pembelajaran kooperatif tipe jigsaw lebih baik dibandingkan dengan model pembelajaran kooperatif tipe STAD; (2) Hasil belajar siswa yang memiliki kecerdasan interpersonal tinggi lebih baik dibandingkan dengan hasil belajar siswa yang memiliki kecerdasan interpersonal rendah; dan (3) Terdapat nteraksi antara model pembelajaran kooperatif dengan kecerdasan interpersonal dalam mempengaruhi hasil belajar PAK.
\end{abstract}

Kata Kunci: model pembelajaran, kooperatif tipe JIGSAW dan STAD, kecerdasan interpersonal, pendidikan agama katolik

Abstract: the objectives of this study are (1) to find out the differences in student learning outcomes that are taught using the Jigsaw type cooperative learning model and the STAD type cooperative learning model in Catholic Religious Education subjects; (2) to find out the difference in learning outcomes of students who have high interpersonal intelligence and students who have low interpersonal intelligence; (3) to determine the interaction between learning models and interpersonal intelligence in influencing the learning outcomes of Catholic Religious Education. Methods in quasi-experimental research. $2 \times 2$ factorial research design. The results showed that: (1) The learning outcomes of Catholic Religious Education students with a jigsaw type cooperative learning model were better than the STAD type cooperative learning model; (2) The learning outcomes of students who have high interpersonal intelligence are better than the learning outcomes of students who have low interpersonal intelligence; and (3) There is interaction between cooperative learning models and interpersonal intelligence in influencing PAK learning outcomes.

Keywords: learning models, JIGSAW and STAD cooperative types, interpersonal intelligence, catholic religious education

\section{PENDAHULUAN}

Pendidikan Agama Katolik pada dasarnya bertujuan agar siswa memiliki kemampuan untuk membangun hidup yang semakin beriman. Membangun hidup beriman Kristiani berarti membangun kesetiaan pada Injil, yang merupakan situasi dan peristiwa penyelamatan: situasi dan perjuangan untuk perdamaian dan keadilan, kebahagiaan dan kesejahteraan, persaudaraan dan kesetiaan, kelestarian lingkungan hidup, yang dirindukan oleh setiap orang dari pelbagai agama dan kepercayaan.

Mata pelajaran Pendidikan Agama Katolik merupakan satu pelajaran yang diajarkan di SMA Swasta St. Maria Tarutung yang memberikan sumbangan terhadap peningkatan pendidikan, walaupun belum optimal. Dari segi Ujian Akhir Semester (UAS) mata pelajaran pendidikan agama masih tergolong di bawah standar.

Kendala yang menjadi dasar kurang maksimal hasil belajar PAK adalah kurangnya 
motivasi siswa untuk memperoleh hasil belajar yang maksimal seperti diungkapkan oleh Yaniati Bali sebagai guru pendidikan agama Katolik SMA St. Maria Tarutung. Hal ini disebabkan oleh pola pikir siswa yang beranggapan bahwa mata pelajaran yang masuk ujian negara lebih penting daripada mata pelajaran yang tidak masuk ujian negara. Pola pikir lain adalah nilai pendidikan agama tidak mungkin dituliskan di bawah nilai standar KKM. Pola pikir ini menyebabkan siswa kurang menunjukkan kreativitasnya dalam proses belajar agama.

Salah satu upaya yang dapat dilakukan adalah penelitian mengenai model pembelajaran koopertif tipe jigsaw dan Student Team Achieve Division (STAD). Dalam model pembelajaran ini guru perlu membantu mengaktifkan siswa untuk berpikir. Hal ini dilakukan dengan membiarkan siswa berjuang dengan persoalan yang ada dan membantu hanya sejauh mereka bertanya dan minta tolong. Guru dapat memberikan orientasi dan arah, tetapi tidak boleh memaksakan arah itu. Tentu saja hal ini membutuhkan waktu lama, tetapi siswa yang berpikir kritis dan mandiri akan siap untuk menghadapi persoalan-persoalan yang baru.

Dalam mengembangkan aspek afektif, teori mengenai sikap kurang memadai, tetapi yang lebih penting adalah pengalaman langsung dan autentik pada saat pembelajaran. John Dewey (dalam Goleman, 1995) menyatakan bahwa pendidikan moral paling ampuh bila diajarkan kepada anak dalam peristiwa nyata, bukan sekedar pelajaran abstrak.

Johnson \& Johnson \& Sutton (Trianto 2011:60) mengungkapkan pembelajaran kooperatif dapat menimbulkan saling ketergantungan positif antara siswa, interaksi siswa semakin meningkat, tanggung jawab individual, keterampilan interpersonal dan kelompok kecil, serta kelangsungan proses kelompok diskusi untuk mencapai tujuan dengan baik. Slavin (dalam Gupta, 2011) menyatakan model yang sangat efektif untuk pembelajaran ini adalah STAD (Student Teams Achievement Division), TAI (Team Assisted Individualization) dan Jigsaw. Roger dan David Johnson dalam Campbell (1996:296) berpendapat strategi jigsaw, pemecahan masalah dan kelompok diskusi mengenai literatur lebih efektif dalam pembelajaran kooperatif.

\section{Hakikat Belajar dan Hasil Belajar Pendidikan Agama Katolik}

Belajar merupakan kegiatan yang paling utama dalam keseluruhan proses pendidikan. Berhasil tidaknya pencapain tujuan pendidikan banyak tergantung pada kualitas proses belajar. Definisi tentang belajar telah banyak dikemukakan oleh para ahli, dan tidak sedikit teori-teori belajar tersebut menimbulkan pertentangan suatu sama lain.

George A. Kimble dalam Hergenhahn \& Olson (2008:8), menyatakan bahwa belajar sebagai perubahan yang relatif permanen di dalam potensi tingkah laku yang terjadi sebagai akibat dari perilaku yang diperkuat. Namun definisi ini tidak diterima secara luas oleh para ahli. Menurut Winkel (1996) belajar adalah suatu aktivitas mental yang berlangung dalam interaksi dengan lingkungannya dan menghasilkan perubahan-perubahan dalam pengetahuan, pemahaman, ketrampilan, nilai, serta sikap.

Mayer dalam Seels \& Richey (1994) dan Sagala (2011:13) menegaskan bahwa belajar menyangkut adanya perubahan yang relatif permanen pada pegetahuan atau perilaku seseorang karena latihan dan pengalaman. Suatu kegiatan dikatakan belajar apabila memiliki tiga ciri-ciri sebagai berikut. Belajar adalah perubahan tingkah laku. Perubahan terjadi karena latihan dan pengalaman, bukan karena pertumbuhan. Perubahan tersebut harus bersifat permanen dan tetap ada untuk waktu yang cukup lama.

Menurut teori konektivisme Thorndike dalam Hergenhahn \& Olson, (2008:61) belajar bersifat incremental (bertahap), bukan insightful (langsung ke pengertian). Belajar berlangsung melalui langkah-langkah kecil yang sistematis melalui seleksi langsung dan pengaitan. Dalam teori ini faktor pengalaman dan pemahaman menjadi sangat penting. Selain itu dalam belajar, pribadi atau organisme memegang peranan yang paling sentral, sebab belajar dilakukan dengan sadar, motif dan tujuan tertentu.

Berkenaan dengan kontinum konkritabstrak dan kaitannya dengan penggunaan media pembelajaran, Brunner seperti yang dikutip oleh Hamid (2009) mengungkapkan bahwa dalam proses pembelajaran hendaknya menggunakan urutan dari (1) tahap enaktif yaitu belajar dengan melakukan aktivitas-aktivitas, (2) tahap ikonik yaitu belajar dengan gambaran atau film, dan (3) tahap simbolik yaitu belajar 
dengan simbol atau menggunakan kata-kata. Dale seperti yang dikutip oleh Seels \& Richey (1994) membuat jenjang konkrit-abstrak yang dimulai dari siswa yang berpartisipasi dalam pengalaman nyata, kemudian menuju siswa sebagai pengamat kejadian nyata, dilanjutkan kepada siswa sebagai pengamat terhadap kejadian yang disajikan dengan media, dan terakhir siswa sebagai pengamat kejadian yang disajikan dengan simbol.

Tidak semua proses perubahan pada manusia dapat dikatakan sebagai proses belajar. Menurut Suprijono (2010), terdapat prinsipprinsip yang mencirikan suatu proses perubahan sebagai proses belajar. Pertama, belajar adalah perubahan perilaku: kedua, belajar merupakan proses; ketiga, belajar merupakan bentuk pengalaman. Perubahan perilaku sebagai hasil belajar memiliki ciri-ciri (a) sebagai tindakan rasional instrumenal yaitu perubahan yang disadari, (b) berkesinambungan dengan perilaku lainnya, (c) fungsional atau bermanfaat sebagai bekal hidup, (d) positif atau berakumulasi, (e) aktif atau sebagai usaha yang direncanakan dan dilakukan, (f) permanen atau tetap, (g) bertujuan atau terarah, dan (h) mencakup seluruh potensi kemanusiaan.

Dalam teori belajar kognitif, Gagne (1988) berpendapat bahwa hasil belajar adalah kemampuan-kemampuan yang dimiliki siswa sebagai akibat perbuatan belajar dan dapat diamati melalui penampilan siswa (learner's performance). Kemampuan-kemampuan ini meliputi informasi verbal, keterampilan intelektual, siasat kognitif, keterampilan motorik dan sikap. Kemampuan ini merupakan hasil interaksi antara kondisi internal siswa berupa potensi dengn kondisi eksternal yang berupa stimulus dari lingkungan melalui proses kognitif.

Bloom (1982) menyatakan hasil belajar menunjukkan proses perkembangan dalam diri siswa yang dikateogrikan dalam tiga aspek kognitif, afektif dan psikomotor. Aspek kognitif meliputi pengetahuan, pemahaman, penerapan, analisis, sinteis dan evaluasi. Pengetahuan dan pemahaman disebut tingkat kognitif rendah. Penerapan, analisis, sinteis dan evaluasi disebut kognitif tingkat tinggi. Aspek afektif mencakup minat, sikap apresiasi, nilai dan emosi. Aspek psikomotor meliputi keterampilan motorik.

Selanjutnya Romizowski

(1981)

menyatakan bahwa hasil belajar diperoleh dalam bentuk pengetahuan dan keterampilan. Pengetahun terdiri dari empat kategori yaitu fakta, konsep, prosedur dan prinsip. Fakta merupakan pengetahuan mengenai obyek, peristiwa atau manusia. Konsep merupakan pengetahuan tentang obyek konkrit atu definisi. Prosedur merupakan pengetahuan tindakan yang bersifat linear dalam mencapai tujuan, Sedangkan prinsip merupakan pernyataan hubungan dua konsep atau lebih.

\section{Hakikat Model Pembelajaran}

Joyce \& Weil (2009:1) berpendapat bahwa model pembelajaran adalah suatu rencana atau pola yang dapat digunakan untuk membentuk kurikulum (rencana pembelajaran jangka panjang), perancang bahan-bahan pembelajaran, dan membimbing pembelajaran di dalam kelas. Proses pembelajaran tidak hanya memiliki makna deskriptif dan aktual, tetapi juga bermakna prospektif dan berorientasi pada masa depan. Arend (2007) berpendapat bahwa model pembelajaran mengacu pada pendekatan yang digunakan, termasuk tujuan pembelajaran, lingkungan pembelajaran, dan pengelolaan kelas. Suprijono (2010) mendefiniskan model pembelajaran sebagai kerangka konseptual yang melukiskan prosedur sistematis dalam mengorganisakan pengalaman belajar untuk mencapai tujuan belajar.

Joyce \& Weil (2009:3) mengelompokkan model-model dalam empat bagian yaitu: (1) model pembelajaran memproses informasi, (2) model pembelajaran kooperatif, (3) model pembelajaran personal, dan (4) model pembelajaran sistem perilaku. Dalam suatu model pembelajaran terdapat empat konsep penting yaitu (1) sintaks yang menunjukkan langkah-lngkah kegiatan yang dilakukandlampembelajaran. (2) sistem sosial yang menggambarkan pernn dan hubungan guru dan siswa, serta aturan-aturan yang diperlukan dalam interaksi sosial cultural. (3) prinsip-prinsip reaksi yang memberi gambaran kepada guru tentang cara menghargai dan merespon pertanyaan-pertanyaan siswa. (4) Sistem penunjang yaitu kondisi yang diperlukan agar model dapat terlaksana secara efektif dan efisien.

Prinsip-prinsip dasar pandangan konstruktivisme menurut Suparno (Trianto, 2011) sebagai berikut: (1) Pengetahuan dibangun sendiri oleh siswa, baik secara personal maupun secara sosial; (2) Pengetahuan tidak dapat dipeindahkan dari guru ke siswa, kecuali hanya dengan keaktifn siswa menalar; 
(3) Siswa aktif merekonstruksi terus-menerus sehingga selalau terjadi konsep ilmiah; (4) Guru berperan sebagai fasilitator menyediakan sarana dan sistuasi agar tercapai konstruksi pengetahuan siswa.

Slavin (1995) mengungkapkan bahwa pembelajaran kooperatif menggalakkan siswa berinteraksi secara aktif dan positif dalam kelompok. Model ini dapat mengoptimalkan dan membangkitkan potensi siswa, menumbuhkan aktivitas serta daya cipta yang menjamin terjadinya dinamika di dalam proses pembelajaran. Model ini juga membuka kemungkinan terjadinya pertukaran ide di antara siswa dalam meningkatkan prestasi belajar tanpa adanya suasana terancam. Dalam proses belajar mengajar, selain aktivitas dan kreativitas, diharapkan juga adanya interaksi sosial yang seimbang. Interaksi yang dimaksud adalah komunikasi antara guru dengan siswa, siswa dengan siswa, dan guru dengan siswa.

Dalam pembalajaran kooperatif siswa belajar bersama dalam kelompok-kelompok kecil yang terdiri dari $4-6$ orang siswa yang sederajat tetapi heterogen, kemampuan, jenis kelamin, suku/ras dan satu sama lain saling membantu (Trianto, 2011: 56). Pembelajaran kooperatif memberikan kesempatan kepada siswa untuk bekerja sama dan terlibat secara aktif dalam proses berpikir dan kegiatan belajar. Siswa bekerja dalam kelompok untuk mencapai ketuntasan materi yang disajikan guru. Siswa bekerja sama dengan sesama siswa dalam tugas-tugas yang terstruktur dan dalam sistem ini guru bertindak sebagai fasilitator.

Rusman (2011:207) menjelaskan ciriciri pembelajaran kooperatif sebagai berikut (1) pembelajaran secara tim, (2) didasarkan pada manajemen kooperatif, (3) Kemauan untuk bekerja sama, dan (4) keterampilan bekerja sama. Pembelajaran kooperatif dicirikan oleh struktur tugas, tujuan dan penghargaan kooperatif. Siswa yang belajar secara kooperatif harus menjalin kerja sama dan saling ketergantungan dalam tugas, tujuan dan hadiah. Sebagai suatu kerja kelompok, mereka harus mengkordinasikan usahanya untuk menyelseaikan tugas bersama.

Model Pembelajaran Kooperatif Tipe Jigsaw

Istilah jigsaw berasal dari bahasa Inggris yang artinya gergaji ukir. Ada juga yang menyebutnya puzzle yaitu sebuah teka-teki menyusun potongan gambar Dalam pembelajaran kooperatif tipe jigsaw siswa melakukan kegiatan pembelajaran dengan cara bekerja sama dengan siswa lain untuk mencapai tujuan bersama (Rusman, 2011:217).

Pembelajaran kooperatif tipe Jigsaw merupakan pembelajaran yang mendorong siswa aktif dan saling membantu dalam menguasai materi pelajaran secara maksimal. Pembelajaran kooperatif tipe jigsaw pertama sekali dikembangkan oleh Elliot Aronson dan teman-temannya di Universitas Texas, dan diadopsi oleh Slavin dn teman-teman di di Universitas John Hopkins (Trianto, 2011: 73). Menurut Lie (1999), "pembelajaran kooperatif model jigsaw ini merupakan model pembelajaran kooperatif dengan cara siswa belajar dalam kelompok kecil yang terdiri dari empat sampai enam orang secara heterogen dan siswa bekerja sama saling ketergantungan positif dan bertanggung jawab secara mandiri" (Rusman, 2011:218).

Menurut Rusman (2011:217) dalam pembelajaranan kooperatif tipe jigsaw siswa bekerja sama untuk menyelesaikan tugas (1) belajar dan manjadi ahli dalam subtopik baginnya; (2) merencanakan bagaimana subtopik baginnya diajarkan kepada anggota kelompok semula. Siswa kembali ke kelompok sebula sebagai "ahli" dalam subtopik bagiannya dan mengajarkan subtopik tersebut kepada temannya. Semua ahli dalam subtopik bagiannya bertindak serupa. Dengan demikian setiap siswa bertanggungjawab untuk menguasai seluruh materi yang ditugaskan oleh guru.

Teknis penerapan tipe pembelajaran ini maju mundur seperti gergaji. Arends (1997) mengungkapkan langkah-langkah penerapan model pembelajaran Jigsaw. (1) Membentuk kelompok heterogen yang beranggotakan $4-6$ orang. (2) Masing-masing kelompok mengirimkan satu orang wakil mereka untuk membahas topik, wakil ini disebut dengan kelompok ahli. (3) Kelompok ahli berdiskusi untuk membahas topik yang diberikan dan saling membantu untuk menguasai topik tersebut. (4) Setelah memahami materi, kelompok ahli menyebar dan kembali ke kelompok masing-masing, kemudian menjelaskan materi kepada rekan kelompoknya. (5) Guru memberikan tes individual pada akhir pembelajaran tentang materi yang telah didiskusikan

Model Pembelajaran Kooperatif Student Team Achieve Division (STAD) 
Model Pembelajaran Kooperatif Student Team Achieve Division (STAD) dikembangkan oleh Slavin (1995) di Universitas John Hopkin. Model ini merupakan salah satu tipe kooperatif yang menekankan aktivitas dan interaki di antara siswa yang untuk saling memotivasi dan saling membantu secara maksimal. Model ini merupakan model kooperatif yang paling sederhana.

Menurut Slavin seperti dikutip Rusman (2011:214) gagasan utama dalam STAD adalah memacu siswa agar belajar saling mendorong dan membantu satu sama lain untuk menguasai ketrampilan yang diajarkan guru. Kelompok siswa yang ingin mendapatkan nilai yang lebih tinggi harus belajar saling mendorong untuk melakukan yang terbaik. Untuk tujuan inilah siswa diberi waktu untuk bekerja sama dan saling membantu setelah guru memberikan materi pelajaran sehingga setiap siswa menguasai pelajaran. Cara siswa untuk saling membantu anggota kelompoknya bervariasi seperti bertukar pasangan, bertukar jawaban, diskusi, saloing memberikn pertanyaan mengenai isi materi pelajaran, menaksir kelbihan dan kekurangan agar berhasil menjalani tes.

Pembelajaran kooperatif tipe STAD mempunyai beberapa keunggulan (Slavin, 1995:17) diantaranya sebagai berikut: Siswa bekerja sama dalam mencapai tujuan dengan menjunjung tinggi norma-norma kelompok. (2) Siswa aktif membantu dan memotivasi semangat untuk berhasil bersama. (3) Sebagai tutor sebaya lebih meningkatkan keberhasilan kelompok. (4) Interaksi antar siswa dapat meningkatan kemampuan mereka dalam berpendapat.

\section{Hakikat Kecerdasan Interpersonal}

Kecerdasan merupakan istilah yang biasa digunakan untuk menjelaskan sifat pikiran yang mencakup sejumlah kemampuan, seperti kemampuan menalar, merencanakan, memecahkan masalah, berpikir abstrak memahami gagasan, menggunakan bahasa dan belajar. Dalam beberapa kasus, kecerdasan bisa termasuk kreativitas, kepribadian, watak, pengetahuan atau kebijaksanaan. Gardner seperti yang dikutip oleh Johnson (2000) mendefinisikan kecerdasan sebagai kemampuan untuk memecahkan masalah atau untuk menciptakan produk yang baru di dalam suatu atau lebih budaya. Sedangkan menurut Rusman (2011) kecerdasan adalah kapasistas global atau terpadu yang dimiliki sesorang yang memungkinkan ia bertindak dengan tujuan, berfikir rasional dan efektif dalam menangani lingkungan. Piaget dalam Hergenhahn \& Olson (2008:313) menjelaskan kecerdasan sebagai inteligensi. Menurutnya inteligensi memungkinkan organisme untuk menangani secara efektif lingkungannya. Tindakan yang cerdas adalah tindakan yang menimbulkan kondisi optimal untuk kelangsungan hidup organisme.

Menurut Lwin (2003) kecerdasan interpersonal adalah kemampuan untuk mengamati dan mengerti maksud, motivasi dan perasaan orang lain. Peka pada ekspresi wajah, suara dan gerakan tubuh orang lain dan ia mampu memberikan respon secara efektif dalam berkomunikasi (Shapiro, 1997). Kecerdasan ini juga mampu untuk masuk ke dalam diri orang lain, mengerti dunia orang lain, mengerti pandangan, sikap orang lain dan umumnya dapat memimpin kelompok. Suparno (2004:80) menyatakan bahwa kecerdasan ini banyak dimiliki oleh para komunikator, fasilitator dan penggerak massa.

Orang yang memiliki kecerdasan tinggi cenderung menjadi ekstrovert, mempunyai sensivitas yang tinggi terhadap orang lain dan senang bekerja sama dalam kelompok. Kecerdasan interpersonal tinggi ditunjukkan melalui kemampuan berkomunikasi secara efektif, mudah empati terhadap orang lain dan dapat menjadi pemimpin. Tipe belajar yang paling sesuai untuk orang ini adalah belajar bersama dan lebih menyenangi diskusi atau debat (Gardner, 2002).

Selanjutnya Suparno

(2004:81) menjelaskan kecerdasan interpersonal memiliki ciri-ciri sebagai berikut: menyukai sosialisasi dengan teman, dapat menjadi pemimpin yang alami, suka memberikan nasihat pada teman yang dalam kesulitan, termasuk dalam klub, komite, atau organisasi, mempunyai lebih dari dua teman dekat, mudah empati kepada rang lain, suka berteman dan kerja sama. Kecerdasan interpersonal ditampakkan melalui kegembiraan berteman dan kesenangan dalam berbagai macam kativitas sosial sert ketidaknyamanan dalam kesendirian dan menyendiri. Orang yang memiliki kecerdasan ini menyukai dan menikmati bekerja secara berkelompok, belajar sambil berinteraksi dan bekerja sama, kerap bertindak sebagai mediator atau penengah dalam perselisihan. Metode belajar bersama 
(pembelajran kooperatif) mungkin sangat baik dipersipkan bagi mereka.

Kecerdasan interpersonal ini mempunyai tiga dimensi utama, yaitu social sensitivity, social insight, dan social communication (Anderson M, 1999). Ketiga dimensi ini merupakan suatu kesatuan yang utuh dan ketiganya saling mengisi satu sama lain. Kecerdasan interpersonal merupakan kecerdasan yang lebih bersifat cristalized menurut konsep yang dikemukakan oleh Cattel (Azwar, 1973).

Rumusan masalah dalam penelitian ini sebagai berikut: (1) Apakah hasil belajar PAK siswa yang diajar dengan model pembelajaran kooperatif tipe jigsaw lebih tinggi daripada siswa yang diajar dengan model pembelajaran tipe STAD?; (2) Apakah hasil belajar Pendidikan PAK siswa yang memiliki kecerdasan interpersonal tinggi lebih tinggi dari siswa yang memiliki kecerdasan interpersonal rendah?; dan (3) Apakah terdapat interaksi model pembelajaran kooperatif dengan kecerdasan interpersonal dalam mempengaruhi hasil belajar Pendidikan Agama Katolik?

\section{METODE}

Penelitian ini dilaksanakan di Sekolah Menengah Atas Swasta St. Maria Tarutung Tapanuli Utara pada siswa kelas XI semester ganjil. opulasi penelitian ini adalah seluruh siswa kelas XI yang terdiri dari tiga kelas dengan jumlah siswa sebanyak 109 orang. Setiap populasi memiliki karakteristik yang sama, umur tidak jauh berbeda, dan menggunakn kurikulum yang sama. Pembagian siswa dalam kelompok belajar di kelas XI tidak ditentukan berdasarkan nilai akademisnya sehingga kemampuan siswa setiap kelas relatif sama. Sampel penelitian ini adalah sebagian dari kelas XI IPA 1 dan XI IPA 2. Teknik pengambilan sampel dalam penelitian ini menggunakan teknik cluster random sampling yaitu dari kelas populasi diambil dua kelas secara acak sebagai kelas sampel. Teknik ini digunakan dengan memperhatikan proporsi setiap kelas dalam strata populasi sehingga sampel yang dipilih merupakan sampel yang representatif dari populasi penelitian. Sampel yang diambil terdiri dari dua kelas yaitu satu kelas dilakukan pembelajaran menggunakan model kooperatif tipe jigsaw dan satu kelas lainnya dilakukan pembelajaran tipe STAD.

Metode yang dipergunakan dalam penelitian ini adalah quasi-eksperimen. Metode ini dipilih karena kelas yang dipakai untuk kelas perlakuan baik kelas pembelajaran dengan kooperatif tipe jigsaw maupun kelas pembelajaran STAD merupakan kelas yang sudah terbentuk sebelumnya dan siswa memiliki tingkat kecerdasan interpersonal yang berbeda.

Desain penelitian yang digunakan adalah desain faktorial $2 \times 2$, yang membandingkan model pembelajaran kooperatif tipe jigsaw dengan model pembelajaran kooperatif tipe STAD terhadap kecerdasan interpersonal tinggi dan kecerdasan interpersonal rendah. Dalam penelitian ini variabel bebas diprediksi memberikan pengaruh terhadap variabel terikat. Variabel model pembelajaran, kecerdasan interpersonal dan hasil belajar pendidikan Agama Katolik dimasukkan ke dalam satu tabel data eksperimen seperti pada table berikut:

Tabel 1. Matriks Rancangan Penelitian

\begin{tabular}{|c|c|c|}
\hline $\begin{array}{c}\text { Model } \\
\text { Pembelajaran (A) } \\
\text { Kecerdasan }\end{array}$ & Tipe jigsaw $\left(\mathrm{A}_{1}\right)$ & Tipe STAD $\left(\mathrm{A}_{2}\right)$ \\
\hline Tinggi $\left(\mathrm{B}_{1}\right)$ & & $\mathrm{A}_{2} \mathrm{~B}_{1}$ \\
\hline Rendah $\left(\mathrm{B}_{2)}\right.$ & $\mathrm{A}_{1} \mathrm{~B}_{1}$ & $\mathrm{~A}_{2} \mathrm{~B}_{2}$ \\
\hline
\end{tabular}

Keterangan:

A $\quad=$ Model Pembelajaran

$\mathrm{B}=$ Kecerdasan Interpersonal

$\mathrm{A}_{1}=$ Model Pembelajaran Kooperatif Tipe Jigsaw

$\mathrm{A}_{2}=$ Model Pembelajaran Kooperatif Tipe STAD
$\mathrm{B}_{1}=$ Kecerdasan Interpersonal Tinggi

$\mathrm{B}_{2}=$ Kecerdasan Interpersonal Rendah

$\mathrm{A}_{1} \mathrm{~B}_{1}=$ Kelompok siswa dengan kecerdasan interpersonal tinggi yang dibelajarkan dengan model pembelajaran kooperatif tipe jigsaw 
$\mathrm{A}_{2} \mathrm{~B}_{1}=$ Kelompok siswa dengan kecerdasan interpersonal tinggi yang dibelajarkan dengan model pembelajaran kooperatif tipe STAD

$\mathrm{A}_{1} \mathrm{~B}_{2}=$ Kelompok siswa dengan kecerdasan interpersonal rendah yang dibelajarkan dengan model pembelajaran kooperatif tipe jigsaw

$\mathrm{A}_{2} \mathrm{~B}_{2}=$ Kelompok siswa dengan kecerdasan interpersonal rendah yang dibelajarkan dengan model pembelajaran kooperatif tipe STAD

Setelah data dikumpulkan perlu dilakukan analisis data. Teknik analisis data yang digunakan adalah teknik statistik deskriptif dan infrensial. Teknik deskriptif digunakan untuk mendeskripsikan data antara lain nilai rata-rata, median, modus, standar deviasi, dan kecenderungan data. Sedangkan teknik statistik inferensial digunakan untuk menguji hipotesis melalui analisis varians (ANAVA) dua jalur dengan taraf signifikan 0,05 .

Sebelum hipotesis dilakukan uji persyaratan analisis yaitu uji normalitas dan uji homogenitas. Uji normalitas menggunakan uji Lillieffors untuk mengetahui apakah data yang diteliti berdistribusi normal atau tidak. vitality , sedangkan untuk uji homogenitas digunakan uji Fisher (F) jika kelompok sampel yang diuji sama dengan 2 digunakan pada hipotesis 1 dan 2 dan uji Barlett jika kelompok sampel lebih dari 2 digunakan pada hipotesis 3.

Selanjutnya untuk keperluan pengujian hipotesis, dirumuskan hipotesis statistik sebagai berikut:
Ha: $\mu \mathrm{A}_{1}>\mu \mathrm{A}_{2}$

2. Ho: $\mu B_{1} \leq \mu B_{2}$

Ha: $\mu B_{1}>\mu B_{2}$

3. Ho: $\mathrm{A}_{1} \mathrm{~A}_{2}><\mathrm{B}_{1} \mathrm{~B}_{2}=0$

$\mathrm{Ha}: \mathrm{A}_{1} \mathrm{~A}_{2}><\mathrm{B}_{1} \mathrm{~B}_{2} \neq 0$

Keterangan:

$\mathrm{A}_{1} \mathrm{~A}_{2}=$ Model Pembelajaran

$\mathrm{B}_{1} \mathrm{~B}_{2}=$ Kecerdasan Interpersonal

$\mu \mathrm{A}_{1}=$ Hasil belajar siswa dengan model pembelajaran kooperatif tipe jigsaw

$\mu \mathrm{A}_{2}=$ Hasil belajar siswa dengan model pembelajaran kooperatif tipe STAD

$\mu \mathrm{B}_{1}=$ Hasil belajar siswa dengan kecerdasan interpersonal tinggi

$\mu \mathrm{B}_{2}=$ Hasil belajar siswa dengan kecerdasan interpersonal rendah

$\mu \quad=$ rata-rata hasil belajar PAK

$\mathrm{A}_{1} \mathrm{~A}_{2}><\mathrm{B}_{1} \mathrm{~B}_{2}=$ Interaksi antara model pembelajaran dengan kecerdasan interpersonal.

Setelah pengujian hipotesis dilakukan pengajian uji lanjut. Uji lanjut yang akan dilakukan adalah uji Scheefe. Hal ini dilakukan karena jumlah n setiap sel tidak sama.

\section{HASIL DAN PEMBAHASAN \\ Hasil}

Berdasarkan data skor tes hasil belajar PAK siswa, langkah berikutnya adalah menghitung total skor dan rata-rata skor tiap kelompok perlakuan menurut tabel ANAVA yang selanjutnya dapat digunakan sebagai dasar keputusan statistik untuk pengujian hipotesis, seperti pada Tabel 2 sebagai berikut:

1. Ho: $\mu \mathrm{A}_{1} \leq \mu \mathrm{A}_{2}$

Tabel 2. Hasil Statistik Deskriptif

\begin{tabular}{|c|c|c|c|c|}
\hline \multirow{2}{*}{\multicolumn{2}{|c|}{$\overbrace{\mathrm{KI}(\mathrm{B})}^{\mathrm{MP}(\mathrm{A})}$}} & \multicolumn{2}{|c|}{ Model Pembelajaran } & \multirow{2}{*}{ Total } \\
\hline & & $\operatorname{Jigsaw}\left(\mathrm{A}_{1}\right)$ & $\operatorname{STAD}\left(\mathrm{A}_{2}\right)$ & \\
\hline \multirow{2}{*}{ 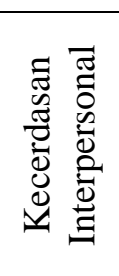 } & Tinggi $\left(\mathrm{B}_{1}\right)$ & $\begin{array}{l}\mathrm{N}=15 \\
\bar{X}=29,600 \\
\mathrm{Sd}=2,550\end{array}$ & $\begin{array}{l}\mathrm{N}=16 \\
\bar{X}=-24.812 \\
\mathrm{Sd}=2.480\end{array}$ & $\begin{aligned} \mathrm{N} & =31 \\
\bar{X} & =27.129 \\
\mathrm{Sd} & =3.471\end{aligned}$ \\
\hline & $\operatorname{Rendah}\left(\mathrm{B}_{2}\right)$ & $\begin{array}{l}\mathrm{N}=20 \\
\bar{X}=22.900 \\
\mathrm{Sd}=4,482\end{array}$ & $\begin{array}{l}\mathrm{N}=18 \\
\bar{X}=23,222 \\
\mathrm{Sd}=4,018\end{array}$ & $\begin{aligned} \mathrm{N} & =38 \\
\bar{X} & =23.052 \\
\mathrm{Sd} & =4,541\end{aligned}$ \\
\hline \multicolumn{2}{|c|}{ Total } & $\begin{array}{l}\mathrm{N}=35 \\
\bar{X}=25,771 \\
\mathrm{Sd}=4,961\end{array}$ & $\begin{array}{l}\mathrm{N}=34 \\
\bar{X}=23,970 \\
\mathrm{Sd}=3,914\end{array}$ & $\begin{aligned} \mathrm{N} & =69 \\
\bar{X} & =24.884 \\
\mathrm{Sd} & =4,570\end{aligned}$ \\
\hline
\end{tabular}

Secara keseluruhan hasil anava untuk pengujian hipotesis dapat dilihat pada Tabel 3 di bawah ini. 
Tabel 3. Rangkuman Hasil Anava Secara Keseluruhan Terhadap Hasil Belajar PAK Rangkuman Anava Faktorial 2 x 2

\begin{tabular}{|l|c|c|c|c|c|}
\hline \multicolumn{1}{|c|}{ Sumber Variasi } & $\mathrm{dk}$ & $\mathrm{JK}$ & $\mathrm{RJK}$ & $\mathrm{F}_{\text {hitung }}$ & $\begin{array}{c}\mathrm{F}_{\text {tabel (1.65) }} \\
(\alpha=0.05)\end{array}$ \\
\hline Model Pembelajaran & 1 & 306.587 & 306.587 & 20.246 & 3.99 \\
\hline Kecerdasan Interpersonal & 1 & 65.156 & 65.156 & 4.302 & \\
\hline Interaksi & 1 & 138.843 & 138.843 & 9.168 & \\
\hline Galat & 65 & 984.281 & 15.142 & & \\
\hline \multicolumn{1}{|c|}{ Total } & 68 & 1494.867 & & & \\
\hline
\end{tabular}

Perbedaan Hasil Belajar Pendidikan Agama Katolik Antara Siswa Yang Memperoleh Model Pembelajaran Kooperatif Tipe Jigsaw dan Kooperatif Tipe STAD adalah

Adapun hipotesis statistik yang diuji

Ho : $\mu \mathrm{A} 1 \leq \mu \mathrm{A} 2$

$\mathrm{Ha}: \mu \mathrm{A} 1>\mu \mathrm{A} 2$

Berdasarkan hasil pengujian hipotesis pada Tabel 3 di atas, maka diperoleh hasil perhitungan data model pembelajaran, di mana $\mathrm{F}_{\text {hitung }}=18,837$, sementara nilai kritik $\mathrm{F}_{\text {tabel }}$ dengan $\mathrm{dk}=(1,65)$ dan $\alpha=0,05$ adalah sebesar 3,99 . Hasil ini menunjukan bahwa $F_{\text {hitung }}=$ $18,837>$ Ftabel $=3,99$ sehingga hipotesis nol (Ho) ditolak, dengan demikian penelitian yang menyatakan bahwa hasil belajar PAK siswa yang dibelajarkan dengan model pembelajaran kooperatif jigsaw lebih tinggi dari pada siswa yang diajarkan dengan model pembelajaran kooperatif STAD teruji kebanarannya.

Perbedaan Hasil Belajar Pendidikan Agama Katolik Antara Siswa Yang Memiliki Kecerdasan Interpersonal Tinggi dan Rendah Adapun hipotesis statistik yang diuji adalah Ho $: \mu \mathrm{A} 1 \leq \mu \mathrm{A} 2$ Ha $: \mu \mathrm{A} 1>\mu \mathrm{A} 2$.

Berdasarkan hasil pengujian hipotesis pada Tabel 4.17 di atas diperoleh hasil perhitungan data kecerdasan interpersonal, di mana $\mathrm{F}_{\text {hitung }}=4.302$, dan nilai kritik $\mathrm{F}_{\text {tabel }}$ dengan $\mathrm{dk}=(1,65)$ dan $\alpha=0,05$ adalah sebesar 3,99 . Hasil ini menunjukan bahwa $\mathrm{F}_{\text {hitung }}=$ $4.302>\mathrm{F}_{\text {tabel }}=3,99$ sehingga hipotesis nol $(\mathrm{Ho})$ ditolak, dengan demikian hipotesis penelitian yang menyatakan bahwa siswa yang memiliki kecerdasan interpersonal tinggi memperoleh hasil belajar PAK lebih tinggi dari pada siswa yang memiliki kecerdasan interpersonal rendah teruji kebenarannya.

Interaksi Antara Model Pembelajaran dan Kecerdasan Interpersonal Siswa Dalam Mempengaruhi Hasil Belajar Pendidikan Agama Katolik

Adapun hipotesis statistik yang diuji adalah

Ho : $\mathrm{A}><\mathrm{B}=0$

$\mathrm{Ha}: \mathrm{A}><\mathrm{B} \neq 0$

Berdasarkan hasil pengujian hipotesis pada Tabel 4.17 di atas, maka diperoleh perhitungan interaksi model pembelajaran dengan kecerdasan interpersonal, di mana $\mathrm{F}_{\text {hitung }}=9.168$ dan nilai kritik $\mathrm{F}_{\text {tabel }}$ dengan $\mathrm{dk}=$ $(1,65)$ dan $\alpha=0,05$ adalah sebesar 3,99. Hasil ini menunjukan bahwa $F_{\text {hitung }}=9.168>$ Ftabel $=$ 3,99 sehingga hipotesis nol (Ho) ditolak, dengan demikian hipotesis penelitian yang menyatakan bahwa terdapat interaksi antara model pembelajaran dan kecerdasan interpersonal dalam memberikan pengaruh terhadap hasil belajar Pendidikan Agama Katolik siswa teruji kebenarannya.

Kerena ada interaksi antara model pembelajaran dan kecerdasan interpersonal dalam mempengaruhi hasil belajar Pendidikan Agama Katolik, maka perlu dilakukan uji lanjutan (post hoc test), untuk mengetahui hasil belajar sampel mana yang berbeda. Untuk melihat interaksi antara model pembelajaran dan kecerdasan interpersonal dalam mempengaruhi hasil belajar Pendidikan Agama Katolik, dilakukan uji lanjut dengan menggunakan uji Scheffe. Ringkasan hasil uji Scheffe dapat dilihat pada Tabel 4 berikut: 
Tabel 4. Ringkasan Hasil Perhitungan Dengan Uji Scheffe

\begin{tabular}{|c|c|c|c|}
\hline \multicolumn{2}{|c|}{ Hasil Hipotesis } & \multirow{2}{*}{$F_{\text {hitung }}$} & $F_{\text {tabel }(3,65)}$ \\
\cline { 3 - 4 } & & $3=0,05$ \\
\hline Ho $: \mu \mathrm{A} 1 \mathrm{~B} 1=\mathrm{A} 2 \mathrm{~B} 1$ & Ho $: \mu \mathrm{A} 1 \mathrm{~B} 1>\mathrm{A} 2 \mathrm{~B} 1$ & 3.432 & 2,75 \\
\hline Ho $: \mu \mathrm{A} 2 \mathrm{~B} 2=\mathrm{A} 1 \mathrm{~B} 2$ & Ho $: \mu \mathrm{A} 2 \mathrm{~B} 2>\mathrm{A} 1 \mathrm{~B} 2$ & 0.255 & 2,75 \\
\hline Ho $: \mu \mathrm{A} 1 \mathrm{~B} 1=\mathrm{A} 1 \mathrm{~B} 2$ & Ho $: \mu \mathrm{A} 1 \mathrm{~B} 1>\mathrm{A} 1 \mathrm{~B} 2$ & 5.054 & 2,75 \\
\hline Ho $: \mu \mathrm{A} 2 \mathrm{~B} 1=\mathrm{A} 2 \mathrm{~B} 2$ & Ho $: \mu \mathrm{A} 2 \mathrm{~B} 1>\mathrm{A} 2 \mathrm{~B} 2$ & 1.192 & 2,75 \\
\hline Ho $: \mu \mathrm{A} 1 \mathrm{~B} 1=\mathrm{A} 2 \mathrm{~B} 2$ & Ho $: \mu \mathrm{A} 1 \mathrm{~B} 1>\mathrm{A} 2 \mathrm{~B} 2$ & 4.701 & 2,75 \\
\hline Ho $: \mu \mathrm{A} 2 \mathrm{~B} 1=\mathrm{A} 1 \mathrm{~B} 2$ & Ho $: \mu \mathrm{A} 2 \mathrm{~B} 1>\mathrm{A} 1 \mathrm{~B} 2$ & 1.468 & 2,75 \\
\hline
\end{tabular}

Kriteria penerimaan jika $\mathrm{F}_{\text {hitung }}>$ $\mathrm{F}_{\text {tabel, }}$ maka teruji secara signifikan. Berdasarkan hasil uji Scheffe pada Tabel 4 di atas dapat dilihat bahwa terdapat enam pasang hipotesis statistik yaitu:

a. hasil penelitian yang menyatakan bahwa hasil belajar PAK siswa jika diajar menggunakan model pembelajaran kooperatif tipe jigsaw lebih tinggi dibandingkan dengan model pembelajaran kooperatif tipe STAD untuk siswa yang memiliki kecerdasan interpersonal tinggi teruji kebenarannya.

b. hasil penelitian yang menyatakan bahwa hasil belajar PAK siswa yang memiliki kecerdasan interpersonal rendah jika diajar menggunakan model pembelajaran kooperatif tipe jigsaw lebih tinggi daripada hasil belajar siswa yang memiliki kecerdasan interpersonal rendah jika diajar dengan model pembelajaran kooperatif tipe STAD tidak teruji kebenarannya. Dengan demikian hasil belajar PAK siswa yang diajar dengan menggunakan model pembelajaran kooperatif jigsaw tidak terdapat perbedaan dibandingkan dengan hasil belajar PAK siswa yang diajar menggunakan model pembelajaran kooperatif STAD untuk siswa yang memiliki kecerdasan interpersonal rendah.

c. hasil belajar PAK siswa dengan kecerdasan interpersonal tinggi jika diajar menggunakan model pembelajaran kooperatif jigsaw lebih tinggi dibandingkan dengan siswa yang memiliki kecerdasan interpersonal rendah teruji kebenarannya.

d. hasil belajar PAK siswa yang memiliki kecerdasan interpersonal tinggi jika diajarkan dengan menggunakan model pembelajaran kooperatif tipe STAD lebih tinggi daripada hasil belajar siswa yang memiliki kecerdasan interpersonal rendah jika diajarkan dengan model pembelajaran kooperatif tipe STAD tidak teruji kebanarannya. Dengan demikian tidak terdapat perbedaan antara hasil belajar PAK siswa yang diajar dengan menggunakan model pembelajaran kooperatif STAD baik yang memiliki kecerdasan interpersonal tinggi maupun rendah yang memiliki kecerdasan interpersonal rendah.

e. hasil belajar PAK siswa dengan kecerdasan interpersonal tinggi jika diajar menggunakan model pembelajaran kooperatif jigsaw lebih tinggi dibandingkan dengan siswa yang memiliki kecerdasan interpersonal rendah yang diajar dengan menggunakan model pembelajaran kooperatif tipe STAD teruji kebenarannya.

f. hasil belajar PAK siswa yang memiliki kecerdasan interpersonal tinggi jika diajar dengan menggunakan model pembelajaran kooperatif tipe STAD lebih tinggi dibandingkan dengan menggunakan model pembelajaran kooperatif tipe Jigsaw untuk kecerdasan interpersonal rendah tidak teruji kebenarannya. Dengan demikian tidak terdapat perbedaan antara hasil belajar siswa yang diajar dengan model pembelajaran kooperatif tipe STAD dan memiliki kecerdasan interpersonal tinggi dengan hasil belajar siswa yang diajar dengan model pembelajaran kooperatif tipe Jigsaw dan memiliki kecerdasan interpersonal rendah. 


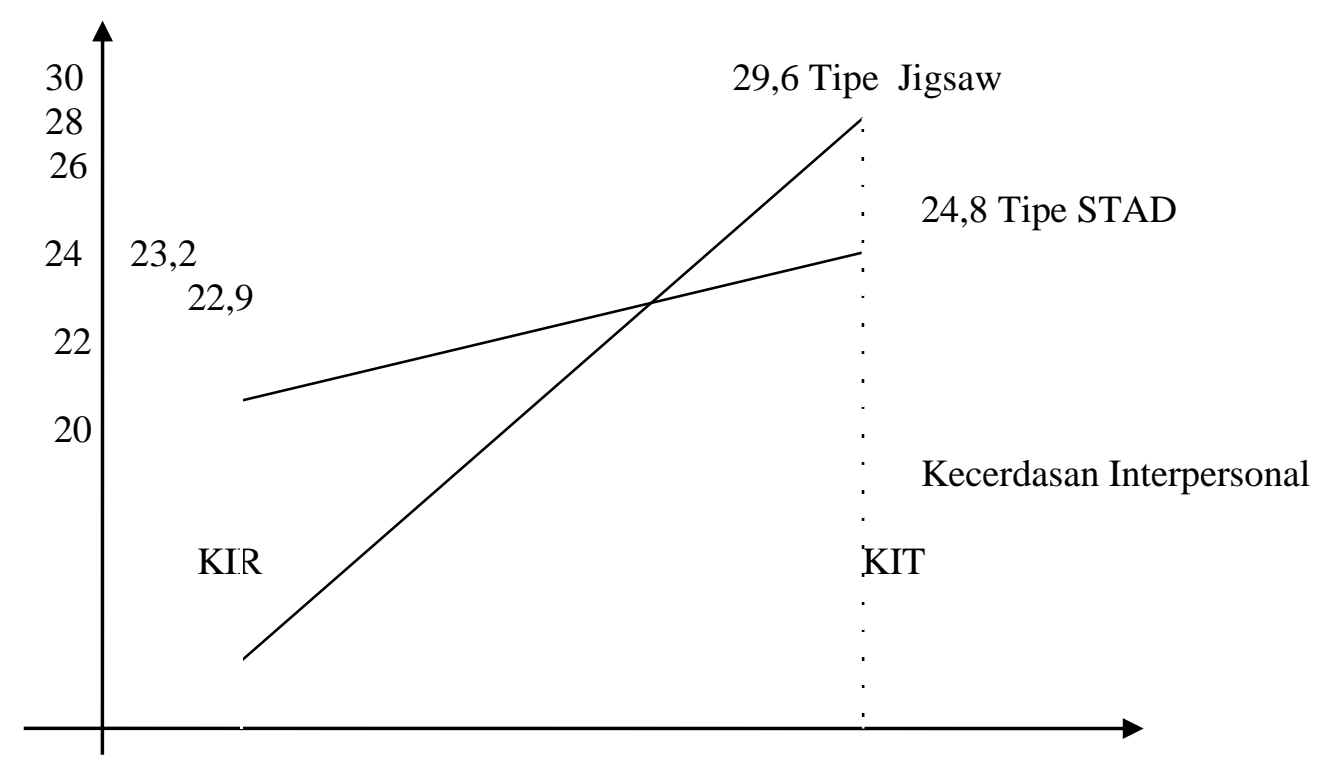

Gambar 1. Model Interaksi Antara Model Pembelajaran Dengan Kecerdasan Interpersonal Terhadap Hasil Belajar Pendidikan Agama Katolik

Hasil Belajar PAK Siswa Yang dibelajarkan Dengan Model Pembelajaran Kooperatif Tipe Jigsaw Lebih Tinggi Dibandingkan Dengan Siswa Yang Dibelajarkan Dengan Model Pembelajaran Kooperatif Tipe STAD

Masalah pendekatan pembelajaran pembelajaran yang kurang sesuai dapat menyebabkan siswa kurang termotivasi untuk mempelajari materi pelajaran. Pembelajaran Pendidikan Agama Katolik seharusnya memacu keingintahuan siswa terhadap materi pelajaran dan mengarahkan siswa untuk mampu mendewasakan imannya. Hal ini dapat tercapai apabila guru mendesain pembelajaran yang di dalamnya terdapat dialog partisipatif antara siswa dengan siswa, dan siswa dengan guru.

Model pembelajaran kooperatif merupakan salah satu pembelajaran kelompok. Model ini dilaksanakan dalam sebuah kelompok kecil dimana siswa saling mengajar untuk mencapai tujuan bersama. Setiap siswa dikondisikan dalam susana pembelajaran yang menyenangkan karena siswa saling membantu dan memberi motivasi. Siswa yang pandai menginformasikan pengetahuannya kepada siswa yang kurang pintar. Siswa yang pasif akan berpartisipasi aktif dalam kelompoknya.

Pembelajaran kooperatif tipe Jigsaw merupakan pembelajaran yang mendorong siswa aktif dan saling membantu dalam menguasai materi pelajaran secara maksimal. Pembelajaran kooperatif tipe jigsaw merupakan model pembelajaran kooperatif dengan cara siswa belajar dalam kelompok kecil yang terdiri dari empat sampai enam orang secara heterogen dan siswa bekerja sama saling ketergantungan positif dan bertanggung jawab secara mandiri.

Model pembelajaran kooperatif tipe STAD mengacu pada belajar siswa dalam kelompok yang beranggotakan empat sampai lima orang. Model ini dapat dikatakan sebagai model siswa tim/kelompok prestasi. Setiap kelompok terdiri dari beragam kemampuan, jenis kelamin dan latar belakang yang berbeda. Anggota tim dapat menggunakan lembar kegiatan atau perangkat pembelajaran yang lain untuk menuntaskan materi pelajaran. Setiap anggota saling membantu untuk memahami bahan pelajaran melalui tutorial atau diskusi.

Prinsip utama dalam model pembelajaran ini adalah siswa agar saling mendorong dan membantu satu sama lain untuk menguasai keterampilan yang diajarkan guru. Kelompok yang ingin mendapatkan nilai lebih tinggi harus belajar dengan saling mendorong untuk melakukan yang terbaik. Siswa diarahkan untuk saling menghargai pendapat dan memberikan kesempatan kepada orang lain untuk mengemukakan gagasannya.

Siswa Yang Memiliki Kecerdasan Interpersonal Tinggi Memperoleh Hasil Belajar PAK Lebih Tinggi Daripada Siswa Yang Memiliki Kecerdasan Interpersonal Rendah

Hasil penelitian menunjukkan bahwa siswa yang memiliki kecerdasan interpersonal tinggi memperoleh nilai rata-rata hasil belajar 
PAK yang lebih baik dibandingkan dengan siswa yang memiliki kecerdasan interpersonal rendah. Kecerdasan interpersonal dipahami sebagai salah satu bentuk karakteristik siswa yang menunjukkan kemampuan siswa untuk bekerjasama, memahami perasaan dan memberi motivasi kepada orang lain. Bila kemampuan ini dikelola dengan baik dalam pembelajaran, siswa yang memiliki motivasi rendah dalam belajar serta sulit bekerja sama dalam tim dapat dipengaruhi oleh siswa yang memiliki motivasi tinggi dan mudah bekerjasama sehingga prestasi belajarnya meningkat.

Dalam PAK siswa dituntut untuk berpartisipasi secara aktif, mengkomunikasikan pengetahuan dan pengalaman hidup dan berinteraksi dalam proses pembelajaran. Sementara siswa yang memiliki kecerdasan interpersonal rendah tidak memiliki kemampuan untuk berpartisipasi aktif dan berkomunikasi. Hal ini dapat menyebabkan siswa tidak berusaha mendapatkan pengetahuan untuk mencapai keberhasilan. Siswa yang memiliki kecerdasan interpersonal rendah cenderung pasif dan sulit bekerja sama dalam memecahkan persoalan sehingga hasil belajarnya tidak maksimal.

Siswa yang memiliki kecerdasan interpersonal tinggi akan memperlihatkan respon yang berbeda dengan siswa yang memiliki kecerdasan interpersonal rendah. Siswa dengan kecerdasan interpersonal tinggi mempunyai kemampuan untuk bekerja secara lebih baik. dibandingkan dengan siswa yang memiliki kecerdasan interpersonal rendah. Dengan kecerdasan interpersonal yang tinggi siswa mengembangkan tingkat pemahaman yang baru melalui bentuk-bentuk interaksi dalam pembelajaran. Sedangkan siswa yang memiliki kecerdasan interpersonal rendah cenderung kurang mampu mengkomunikasikan materi pelajaran, pengalaman hidup yang berkaitan dengan materi pembelajaran sehingga tidak mempunyai kemampuan untuk berprestasi dibandingkan dengan siswa yang lain.

Siswa yang cerdas secara interpersonal lebih mampu menggunakan cara-cara yang beragam dalam belajar dan membentuk hubungan sosial dengan orang lain untuk mempercepat proses pemecahan masalah belajarnya. Kemampuan ini akan berpengaruh terhadap peningkatan prestasi belajarnya. Apabila kecerdasan interpersonal tinggi, siswa diduga akan mempunyai prestasi yang baik dalam belajar. Sedangkan siswa yang mempunyai kecerdasan interpersonal rendah kurang mampu menggunakan cara-cara yang beragam dalam belajar dan membentuk hubungan sosial dengan orang lain, sehingga dengan kecerdasan interpersonal yang rendah juga akan mempengaruhi peningkatan hasil belajar yang rendah. Apabila kecerdasan interpersonal siswa rendah, siswa itu diduga akan mempunyai prestasi yang rendah.

Berdasarkan uraian di atas dapat dipahami bahwa siswa yang mempunyai kecerdasan interpersonal tinggi memperoleh hasil belajar PAK yang lebih tinggi dibandingkan dengan siswa yang mempunyai kecerdasan interpersonal rendah.

Terdapat Interaksi Antara Model Pembelajaran Dan Kecerdasan Interpersonal Dalam Mempengaruhi Hasil Belajar PAK

Hasil penelitian ini menunjukkan bahwa terdapat interaksi antara model pembelajaran dan kecerdasan interpersonal dalam mempengaruhi hasil belajar PAK SMA Swasta St. Maria Tarutung. Model pembelajaran kooperatif tipe jigsaw memberi tekanan pada diskusi dengan topik yang berbeda kepada setiap anggota kelompok dan selanjutnya setiap anggota diarahkan supaya menjadi tim ahli dalam topik pembahasannya. Kelompok ahli yang terdiri dari anggota kelompok asal ditugaskan untuk mempelajari dan mendalami topik tertentu. Kemudian setiap tim ahli menjelaskan topik pembahasannya kepada kelompok asal masing-masing. Dengan demikian setiap siswa saling tergantung dan bekerjasama untuk mempelajari materi yang ditugaskan.

Siswa yang memiliki kecerdasan interpersonal tinggi dan diajar dengan menggunakan model pembelajaran kooperatif tipe jigsaw mempunyai hasil belajar yang lebih baik dibandingkan dengan kelompok siswa yang memiliki kecerdasan interpersonal tinggi tetapi diajar dengan model pembelajaran kooperatif tipe STAD. Hal ini dapat dipahami karena siswa yang memiliki kecerdasan interpersonal tinggi akan berusaha untuk mengungkapkan apa yang diketahuinya kepada orang lain. Selain itu siswa tersebut berlomba untuk memecahkan masalah dalam pembelajaran. Kelompok siswa yang memiliki kecerdasan interpersonal tinggi dan diajar dengan model pembelajaran kooperatif tipe STAD akan memperoleh hasil belajar yang kurang maksimal, sebab pembelajaran dengan 
model STAD kurang mengeksplorasi kemampuan siswa.

Kelompok siswa yang memiliki kecerdasan interpersonal rendah lebih baik diajar dengan menggunakan model pembelajaran kooperatif tipe STAD daripada menggunakan model pembelajaran kooperatif tipe jigsaw. Siswa yang memiliki kecerdasan interpersonal rendah dan diajar dengan model pembelajaran kooperatif tipe jigsaw akan menimbulkan kebosanan dan tidak dapat berinteraksi secara aktif seperti siswa yang memiliki kecerdasan interpersonal tinggi. Hal ini menghambat perkembangan cara belajarnya dan hasil belajarnya jug tidak maksimal. Untuk memaksimalkan hasil belajar siswa yang memiliki kecerdasan interpersonal rendah, penerapan model pembelajaran kooperatif tipe STAD lebih sesuai dibandingkan dengan tipe jigsaw karena siswa cenderung mendengarkan dan menerima pengetahuan yang diungkapkan oleh anggota kelompoknya. Bila terjadi diskusi dalam kelompok siswa yang memiliki kecerdasan interpersonal rendah sulit membangun dan mempertahankan relasi sosial serta memahami perasaan orang orang lain.

\section{PENUTUP}

1. Hasil belajar Pendidikan Agama Katolik siswa dengan model pembelajaran kooperatif tipe jigsaw lebih baik dibandingkan dengan model pembelajaran kooperatif tipe STAD. Siswa yang dibelajarkan dengan menggunakan model pembelajaran kooperatif tipe jigsaw lebih baik dibandingkan model pembelajaran kooperatif tipe STAD dalam materi pelajaran yang sama.

2. Hasil belajar siswa yang memiliki kecerdasan interpersonal tinggi lebih baik dibandingkan dengan hasil belajar siswa yang memiliki kecerdasan interpersonal rendah. Siswa yang memiliki kecerdasan interpersonal tinggi memperoleh hasil belajar lebih baik dibandingkan siswa yang memiliki kecerdasan interpersonal rendah dalam materi pelajaran yang sama.

3. Terdapat interaksi antara model pembelajaran kooperatif dengan kecerdasan interpersonal dalam mempengaruhi hasil belajar PAK . Untuk siswa yang memiliki kecerdasan interpersonal tinggi akan lebih efektif dalam meningkatkan hasil belajar PAK jika menggunakan model pembelajaran kooperatif tipe jigsaw, sedangkan untuk siswa yang memiliki kecerdasan interpersonal rendah lebih efektif dalam meningkatkan hasil belajar PAK dengan menggunakan model pembelajaran kooperatif tipe STAD.

\section{DAFTAR PUSTAKA}

$\begin{array}{ccr}\text { Anita } & \text { Lie } \quad(1999: 30), & \text { dalam } \\ \text { http//luarsekolah.blogspot.com } & \text { diakses } \\ \text { tanggal 21 Oktober 2011 } & \end{array}$

Anderson, L.W \& Krathwohl (Eds). (2010). A Taksonomi for Learning, Teaching and Acessing: A Revision of Bloom's Taxonomy of Educational Obyektives. Terjemahan oleh Agung Prihantoro. Yogyakarta: Pustaka Pelajar.

Anderson, M. (1999). The Development of Intelligence. Uk: Psychologicl Press.

Arends, R. (2007). Learning to Teach.Terjemahan oleh Helly Prajitno Soetjipto \& Sri Muyantini

Azwar, S.(2002). Penyusunan Skala Psikologi. Yogyakarta: Pustaka Pelajar

Bloom, Benyamin S.(1982). Human Characteristic and School Learning. New York: Mc Graw Hill. Book company.

Campbell, Linda. (1996). Teaching and Learning though Multiple Intelligences.Massachusetts: Media Link Associates Inc.

Gagne, Robert M dan Driscoll (1988). Essentials of Learning For Instruction. Englewood Cliffs, NJ: Prantice-Hall, Inc.

Gardner, H. (2002). "Interpersonal Communication amongst Multiple Subjects: A Study in Redundancy," Experimental Psychology (2002).

Goleman, D.(1995). Emotional Intelligence. Terjemahan oleh T.Hermaya.1996. Cetakan ke-18, Jakarta: Gramedia Pustaka Utama.

Gupta, M. \& Pasrija, P. (2011). Co-operative Learning : an Efficient Technique to Convert Students Into Active Learners in Classrooms. New Frontiers in Education.

Hamid, A. K. 2009. Teori Belajar dan Pembelajaran.Medan: Edisi Kedua, (tanpa penerbit).

Hergenhahn, B.R., Olson, M.H. (2008). Theories of Learning. Terjemahan oleh Triwibowo B.S.2008.Jakarta: Kencana Prenada Media Group. 
Joice B., Weil,M., Calhoun,E.(2009). Models of Teaching. Terjemahan oleh Achmad Fawaid dan Ateilla Mirza. Yogyakarta: Pustaka Pelajar.

Lwin, M., Khoo, A., Lyen, K., (2003). Cara Mengembangkan Berbagai Komponen Kecerdasan. Terjemahan oleh Christine Sujana.2008. Macanan Jaya Cemerlang.

Romizowski, A.J. (1981). Designing Instructional Sistem. Decisio Making in Course Planning and Curriculum Design. New York: Nicolas

Rusman. (2011). Model-Model Pembelajaran: Mengembangkan Profesionalisme Guru, cetakan ke - 2, Jakarta: Rajagrafindo Persada.

Sagala, S. (2011). Konsep dan Makna Pembelajaran. Cetakan ke-9, Bandung: Alfabeta

Seels,B.B., Richey , R.C.(1994). Instructional Tecnology: The Defenition and Domains of the Field. Terjemahan oleh Yusufhadi Miarso, dkk. Tanpa tahun terjemahan. Jakarta: Ikatan Profesi Teknologi Pendidikan Indonesia (IPTPI).

Slavin, R.E., (1995). Cooperative Learning Theory. Allyn and Bacon Publisher

Suparno, P.,(2004). Teori Inteligensi Ganda dan Aplikasinya di Sekolah: Cara Menerapkan Teori Multiple Intelligence Howard Gardner.Cetakan ke-8.Jakarta: Kanisius.

Suprijono, A. (2010). Cooperative Learning, Teori dan Aplikasi PAIKEM. Cetakan ke4, Yogyakarta: Pustaka Pelajar.

Trianto, (2009). Mendesain Model Pembeljaran Inovatif Progressif.Cetakan ke-9. Jakarta: Kencana Prenada Media Group.

Winkel, W.S. (1996). Psikologi Pengajaran. Jakarta: Gramedia 